\title{
Macrophytes and Charophytes in Ecological Assessment of the Protected Lakes in Donetsk Region, Ukraine
}

\author{
Sophia Barinova ${ }^{1, *}$, Andrew Fatyukha ${ }^{2}$, Roman Romanov ${ }^{3}$ \\ ${ }^{1}$ Institute of Evolution, University of Haifa, Israel \\ ${ }^{2}$ Donetsk Botanical Garden of the National Academy of Sciences of Ukraine, Ukraine \\ ${ }^{3}$ Central Siberian Botanical Garden, Siberian Branch of the Russian Academy of Sciences, Russia \\ *Corresponding Author: barinova@research.haifa.ac.il
}

Copyright (C) 2014 Horizon Research Publishing All rights reserved.

\begin{abstract}
First study of macrophytes and Charophytes of three protected lakes in Donetsk region of Ukraine has been implemented for ecological assessment of the lakes environment by bio-indication methods. Altogether five species of mactophytes and three species of macroalgae were revealed. Rare species Chara dominii Vilh. was found in massive grow in the Flora Lake. The lakes Flora and Molodezhnyy are mesotrophic and low-to middle organic polluted, while the Azotnyy Lake is oligotrophic, low organically polluted. Statistical methods show that organic pollution come mostly from ground waters enriched by mine waters, and together with soluble sodium from surface runoff they are stimulated species growth. Lake Molodezhnyy can be used as referent site for monitoring, whereas the Azotnyy Lake needs more attention in study of toxic substances, and the Flora Lake for organic matter influence. Bio-indication methods together with statistic approaches can be used as sensitive instrument for ecosystem state assessment and watershed protection in the technogenically impacted area such as Donetsk region of Ukraine.
\end{abstract}

Keywords Macrophytes, Charophytes, Ecology, Bio-indication, CCA, Lakes, Ukraine

\section{Introduction}

Freshwater algae are widely used as bio-indicators of aquatic environment [1] but ecological assessment with algal, charophytes, and macrophyte aquatic plants is in Ukraine in initial step only [2-4]. Avoid species ecology and its habitats, in Ukraine mostly give attention to some biological activities of this species with detailed description of species morphology and floristic aspects [5].

Center industry of South-East Ukraine is Donetsk, where a small area centered metallurgical, machine-building, chemical plants and coal mines that discharge large amounts of wastewater [6]. Such intense exposure leads to disruption of the ecological status of water bodies and requires an evaluation of different methods. The main waterway flowing through the center of the city of Donetsk is the river Kalmius. Its river basin in the territory of Donetsk is regulated by plenty of water reservoirs and ponds and is a convenient model for monitoring studies of surface waters in the region that is under long-term anthropogenic press [6]. Studies of aquatic vegetation ponds Donetsk held for more than 30 years ago [7-10] and do not reflect the current state of the flora. Bio-indication methods of Donetsk water bodies' assessment was not performed [11]. Our research of macrophytes was partially covered in the paper [12] but still remain in initial stage.

In recent, bio-indication approach in the Eastern Mediterranean and Black Sea basins is rather developed $[2-4,13]$ not only with microscopic algae but also with charophytes macroalgae [14,15]. We implemented of summarized information about species autecology [16,17] for macrophytes and macroalgal community from the three different lakes in purpose to characterize the environment in each lake that are important as recreation and wildlife objects.

The aim of present study is to identify of Charophytes that studied firstly for this lakes locality in Ukraine, to characterize the lake environment by bio-indication methods on the base of revealed diversity of algae and macrophytes.

\section{Materials and Methods}

\subsection{Sampling and Laboratory Studies}

The macrophytes samples were collected by Andrew Fatyukha during 2012-2014 monthly field trips from 0-70 $\mathrm{cm}$ depth of each studied lake. Charophyte samples were taken in each lake by scooping. Both, macrophyte and charophyte samples were herbarized and transported to the Donetsk Botanical Garden for microscope studies. Part of the charophyte samples were sent to the Institute of 
Evolution, University of Haifa and studied under Nikon light microscope and Leica stereomicroscope with digital cameras under magnification $\times 100-1000$. Part of charophyte samples was sent to the Central Siberian Botanical Garden and studied under stereomicroscope Carl Zeiss Stereo Discovery V12 and micrographs were taken with the digital camera AxioCam MRS-S and Axiovision 4.8 software.

Charophytes were treated with $\mathrm{HCl}$ to remove calcium carbonate. The structure elements were observed with Nikon with digital camera, DinoLight camera, and light microscopes (LM) in the Institute of Evolution, University of Haifa and the Central Siberian Botanical Garden SB RAS with help of international handbooks [18-20]. Macrophyte and charophyte abundance were assessed as percentage scale in each lake.

Elemental analysis of water samples was carried out in the research laboratory of "Lux", Donetsk, Ukraine. A large suite (33 total) of elements (Ag, Al, As, B, Ba, Be, Bi, Ca, $\mathrm{Cd}, \mathrm{Co}, \mathrm{Cr}, \mathrm{Cu}, \mathrm{Fe} \mathrm{K}, \mathrm{Li}, \mathrm{Mg}, \mathrm{Mn}, \mathrm{Mo}, \mathrm{Na}, \mathrm{Ni}, \mathrm{P}, \mathrm{Pb}, \mathrm{S}, \mathrm{Sb}$, $\mathrm{Se}, \mathrm{Si}, \mathrm{Sn}, \mathrm{Sr}, \mathrm{Ti}, \mathrm{V}, \mathrm{W}, \mathrm{Zn}, \mathrm{Zr}$ ) were quantified by inductively coupled plasma atomic emission spectrophotom eter (ICP-OES) Shimadzu ICPE-9000 according to DSTU ISO 11885:2005.

Statistical analysis of the correlation between species diversity and major water condition variables was calculated by distance-weighted least squares using the Statistica 7.1 Program.

Statistical significance of variables was assessed using the Pearson correlation method with wessa.net.

Canonical Correspondence Analysis (CCA) with CANOCO for Windows 4.5 package [21] was used to determine the relationships of species diversity in algal communities and their environmental variables.

\subsection{Description of the Study Site}

Three lakes selected for study are located in the city of Donetsk and its industrial zone (Figure 1). Lakes are seasonally fluctuated in water transparency and biomass of macrophytes. Lakes are used for purpose of recreation and wildlife. Area and length of the shoreline counted using the site cadastral maps of Ukraine (http://www.map.land.gov.ua /kadastrova-karta), coordinates with cards Google (https://www.google.com.ua/ maps).

The Azotnyy Lake (Figure 2) is placed in the Pushkin Park of Donetsk, in the upper right tributary Durnaya of the Kalmius River with $48^{\circ} 00^{\prime} 36.4^{\prime \prime N} 37^{\circ} 44^{\prime} 47.8^{\prime \prime}$. Surface area is about 1.7 hectares, the shoreline $700 \mathrm{~m}$, shallow, muddy, along the causeway passes a busy highway, the upper part overgrown with macrophytes. Near the lake is located the Donetsk plant of chemicals, but direct discharges are not exist. Lake is used for purpose of wildlife. Sample was collected in the silty sand bottom 2 meters from the shore at a depth of $50 \mathrm{~cm}$.

The Molodezhnyy Lake (Figure 3) of Donetsk Botanical Garden is located in the arboretum botanical garden, in the upper left tributary Bogodukhov of the Kalmius River coordinates with $48^{\circ} 00^{\prime} 10.0^{\prime \prime} \mathrm{N} 37^{\circ} 53^{\prime} 04.7^{\prime \prime} \mathrm{E}$. Surface area is about 3.9 hectares, the shoreline $890 \mathrm{~m}$, deep, muddy, direct discharges are absent, in personal observations with transparent water throughout the year that is non-typical for Donetsk ponds. Samples were collected in the silty bottom, about 2 meters from the shore at a depth of $50 \mathrm{~cm}$, where macrophytes form dense thickets.

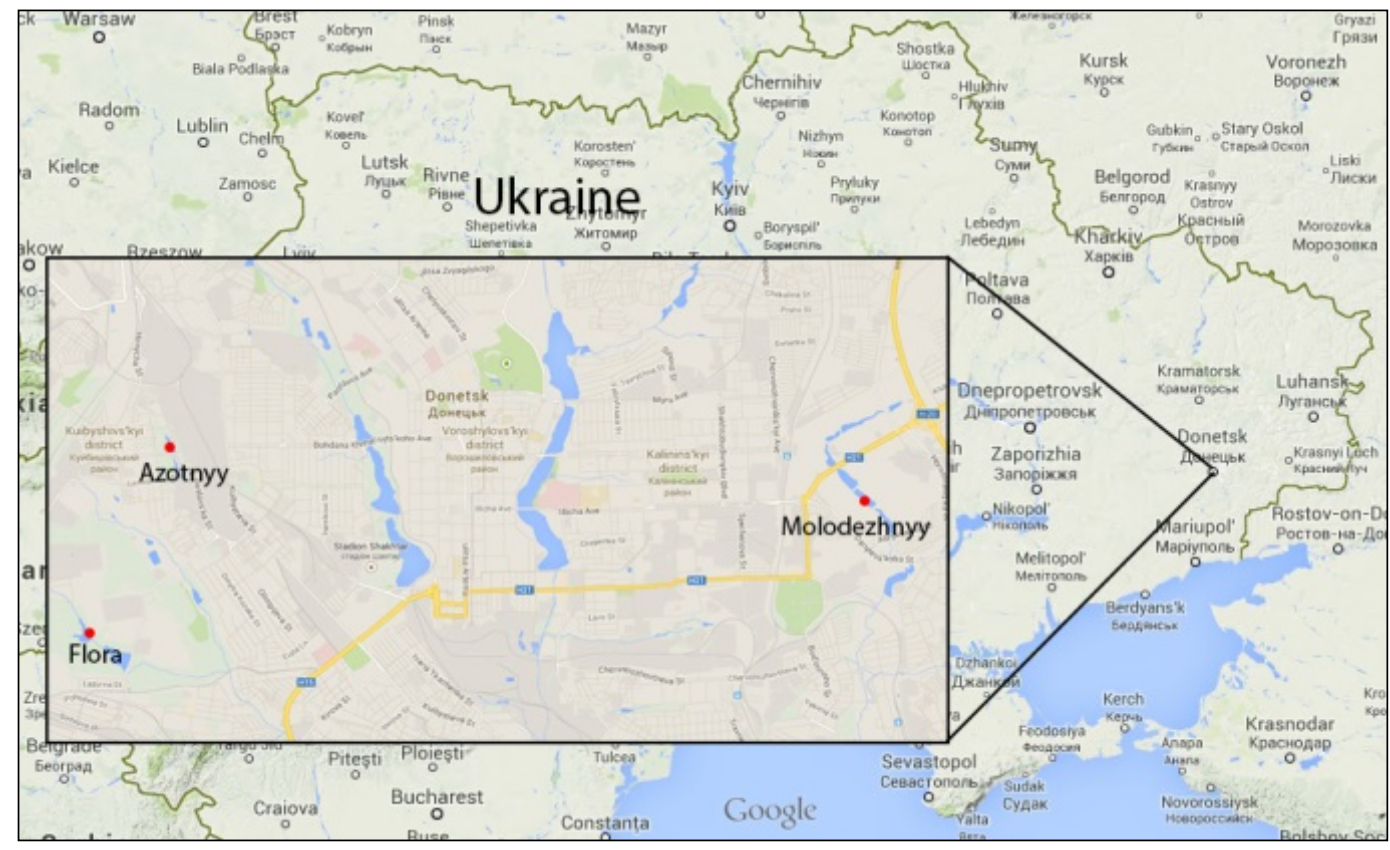

Figure 1. Three studied water bodies in the Donetsk region, Ukraine. 


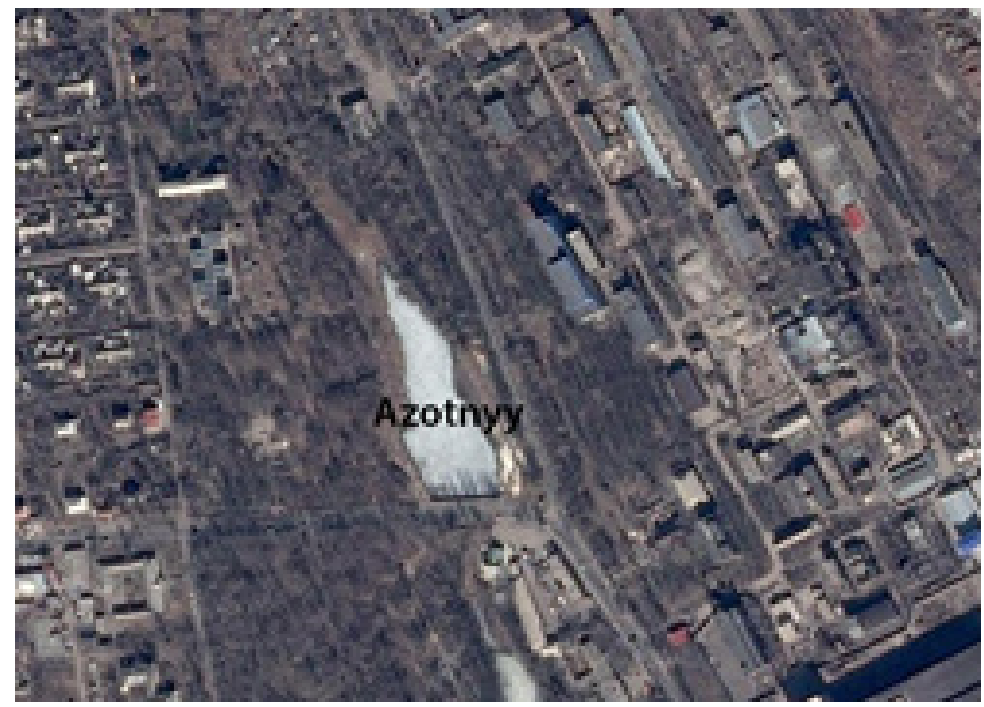

Figure 2. The Azotnyy Lake area in the Donetsk region, Ukraine.

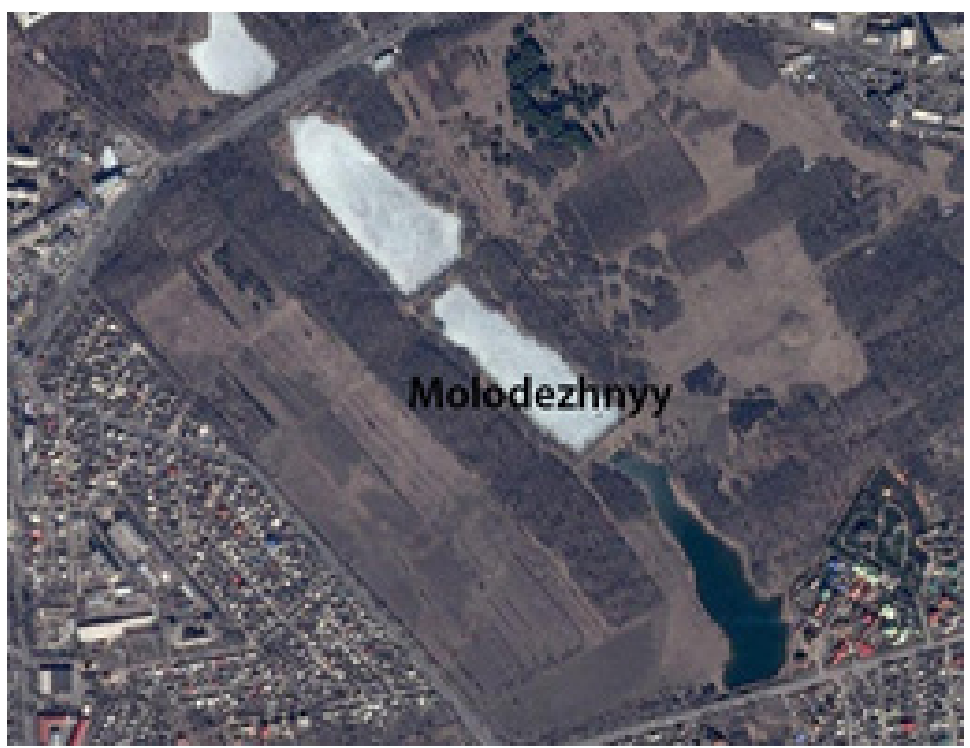

Figure 3. The Molodezhnyy Lake area in the Donetsk region, Ukraine.

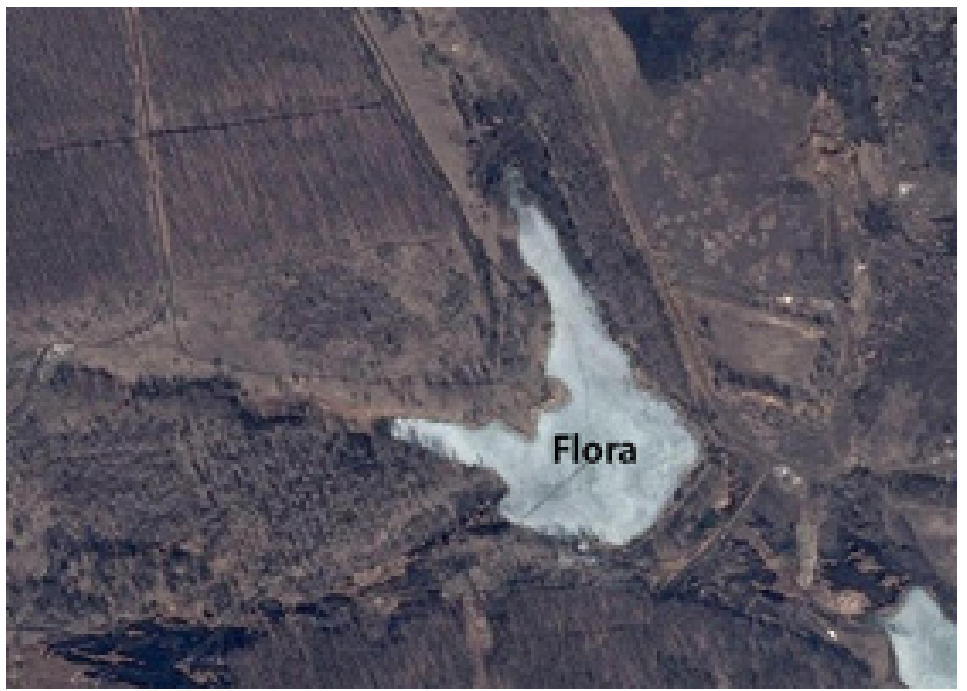

Figure 4. The Flora Lake area in the Donetsk region, Ukraine. 
The Flora Lake (Figure 4) is located in a forested area in the upper right tributary Durnaya of the Kalmius River with coordinates $47^{\circ} 59^{\prime} 04.5^{\prime \prime} \mathrm{N} 37^{\circ} 43^{\prime} 45.9^{\prime \prime} \mathrm{E}$. Surface area is about 4 hectares, the shoreline $1200 \mathrm{~m}$, deep, muddy, located near two mine dump, direct discharges are not exist. Samples were collected in the silty sand bottom, about 3 meters from the shore at a depth of $50 \mathrm{~cm}$, where macrophytes form dense thickets.

\section{Results and Discussion}

\subsection{Chemical Composition of the Lakes Water}

Chemical variables were measured in three studied lakes between April 2012 and October 2013. Can be seen (Table 1) that chemical variables reflected low polluted waters [13, 16] which enriched by calcium, magnesium, and mostly sodium and sulfates. Water Quality Class has been assessed when it possible for elements according [16]. The Azotnyy Lake water was saturated round the year with iron, potassium and manganese, while calcium, lithium, magnesium, sodium, sulfate, silicon and strontium were significantly lower than in the lakes Flora and Molodezhnyy. That show environmental differences between the Azotnyy Lake that can be classified as under anthropogenic impact, and lakes Flora and Molodezhnyy, which looks like more natural because are located in a forested area (Figures 3-4).

Table 1. Chemical variables in the studied lakes water ( $\left.\mathrm{mg} \mathrm{l}^{-1}\right)$. Standard according to [16], Table 22. Carbonate rock: Pristine streams draining most common carbonate rock types; DWNC: Global Discharge-Weighted Natural Concentration. Water Quality Class: according to [16], Table 5.

\begin{tabular}{|c|c|c|c|c|c|c|c|c|c|c|c|c|c|c|c|}
\hline Water body & $\begin{array}{c}\text { Sampling } \\
\text { date }\end{array}$ & B & $\mathrm{Ba}$ & $\mathrm{Ca}$ & $\mathrm{Fe}$ & $\mathrm{K}$ & $\mathrm{Li}$ & $\mathrm{Mg}$ & $\mathrm{Mn}$ & $\mathrm{Na}$ & $\mathrm{P}$ & $\mathrm{S}$ & $\mathrm{Si}$ & $\mathrm{Sr}$ & $\mathrm{Zn}$ \\
\hline Flora & Apr-12 & 0.77 & 0.03 & 160 & 0.005 & 3.56 & 0.10 & 126.0 & 0.004 & 567 & 0.01 & 635 & 2.46 & 2.78 & 0.001 \\
\hline Flora & May-12 & 0.86 & 0.03 & 199 & 0.003 & 4.46 & 0.11 & 135.0 & 0.001 & 575 & 0.01 & 618 & 1.22 & 5.70 & 0.001 \\
\hline Flora & June-12 & 0.74 & 0.04 & 184 & 0.001 & 4.43 & 0.11 & 141.0 & 0.003 & 524 & 0.02 & 418 & 2.80 & 5.12 & 0.002 \\
\hline Flora & July-12 & 0.78 & 0.04 & 152 & 0.001 & 4.64 & 0.13 & 143.0 & 0.001 & 549 & 0.35 & 404 & 3.20 & 5.51 & 0.002 \\
\hline Flora & Aug-12 & 0.58 & 0.04 & 206 & 0.001 & 3.83 & 0.11 & 142.0 & 0.001 & 675 & 0.05 & 467 & 5.73 & 4.39 & 0.002 \\
\hline Flora & Sep-12 & 0.77 & 0.03 & 172 & 0.002 & 2.06 & 0.10 & 152.0 & 0.002 & 332 & 0.00 & 450 & 4.05 & 4.49 & 0.003 \\
\hline Flora & Oct-12 & 0.79 & 0.03 & 156 & 0.004 & 4.61 & 0.13 & 154.0 & 0.006 & 611 & 0.17 & 480 & 4.16 & 6.16 & 0.004 \\
\hline Flora & Nov-12 & 0.69 & 0.03 & 136 & 0.005 & 3.64 & 0.15 & 141.0 & 0.007 & 624 & 0.03 & 352 & 3.52 & 6.96 & 0.004 \\
\hline Flora & Apr-13 & 0.69 & 0.04 & 174 & 0.003 & 4.22 & 0.13 & 134.0 & 0.004 & 506 & 0.01 & 506 & 4.53 & 5.89 & 0.003 \\
\hline Flora & July-13 & 0.71 & 0.04 & 168 & 0.003 & 4.36 & 0.12 & 140.0 & 0.007 & 578 & 0.14 & 485 & 4.29 & 6.73 & 0.002 \\
\hline Flora & Oct-13 & 0.71 & 0.04 & 175 & 0.004 & 4.74 & 0.11 & 156.0 & 0.007 & 603 & 0.17 & 439 & 5.75 & 5.88 & 0.004 \\
\hline Molodezhnyy & Apr-12 & 0.55 & 0.03 & 133 & 0.008 & 4.31 & 0.04 & 75.5 & 0.004 & 288 & 0.00 & 456 & 2.57 & 1.75 & 0.003 \\
\hline Molodezhnyy & May-12 & 0.55 & 0.04 & 155 & 0.006 & 5.70 & 0.05 & 85.6 & 0.003 & 330 & 0.01 & 450 & 0.54 & 3.66 & 0.004 \\
\hline Molodezhnyy & June-12 & 0.44 & 0.03 & 146 & 0.002 & 5.94 & 0.06 & 108.0 & 0.002 & 372 & 0.02 & 350 & 0.39 & 3.56 & 0.002 \\
\hline Molodezhnyy & July-12 & 0.51 & 0.04 & 107 & 0.002 & 5.48 & 0.06 & 96.1 & 0.002 & 352 & 0.34 & 326 & 0.72 & 3.62 & 0.003 \\
\hline Molodezhnyy & Aug-12 & 0.40 & 0.03 & 164 & 0.002 & 5.55 & 0.06 & 98.7 & 0.002 & 470 & 0.05 & 401 & 1.79 & 3.09 & 0.004 \\
\hline Molodezhnyy & Sep-12 & 0.52 & 0.03 & 136 & 0.003 & 2.96 & 0.06 & 89.3 & 0.006 & 232 & 0.00 & 335 & 1.47 & 3.22 & 0.005 \\
\hline Molodezhnyy & Oct-12 & 0.56 & 0.03 & 109 & 0.005 & 6.11 & 0.07 & 97.5 & 0.006 & 389 & 0.17 & 424 & 1.47 & 4.20 & 0.005 \\
\hline Molodezhnyy & Nov-12 & 0.64 & 0.05 & 189 & 0.005 & 6.06 & 0.11 & 127.0 & 0.009 & 565 & 0.03 & 387 & 2.08 & 5.98 & 0.005 \\
\hline Molodezhnyy & Apr-13 & 0.58 & 0.02 & 127 & 0.007 & 5.44 & 0.07 & 83.0 & 0.004 & 357 & 0.01 & 421 & 1.62 & 2.55 & 0.002 \\
\hline Molodezhnyy & July-13 & 0.62 & 0.04 & 132 & 0.008 & 5.94 & 0.07 & 101.0 & 0.002 & 364 & 0.29 & 504 & 1.51 & 3.51 & 0.003 \\
\hline Molodezhnyy & Oct-13 & 0.59 & 0.04 & 136 & 0.008 & 5.73 & 0.07 & 107.0 & 0.006 & 376 & 0.12 & 474 & 1.34 & 4.62 & 0.004 \\
\hline Azotnyy & Apr-13 & 0.42 & 0.03 & 67 & 0.055 & 10.40 & 0.03 & 63.8 & 0.301 & 168 & 0.00 & 144 & 1.05 & 0.98 & 0.003 \\
\hline Azotnyy & July-13 & 0.44 & 0.03 & 70 & 0.068 & 11.90 & 0.02 & 67.8 & 0.317 & 180 & 0.03 & 159 & 1.20 & 1.22 & 0.002 \\
\hline Azotnyy & Oct-13 & 0.42 & 0.03 & 75 & 0.062 & 12.80 & 0.04 & 70.1 & 0.348 & 191 & 0.04 & 162 & 1.53 & 1.44 & 0.003 \\
\hline $\begin{array}{c}\text { Carbonate } \\
\text { rock }\end{array}$ & & n.a. & n.a. & 2560 & n.a. & 13 & n.a. & 640 & n.a. & 34 & n.a. & 39 & 47 & n.a. & n.a. \\
\hline DWNC & & n.a. & n.a. & 670 & n.a. & 32 & n.a. & 259 & n.a. & 159 & n.a. & 54 & 136 & n.a. & n.a. \\
\hline $\begin{array}{c}\text { Water } \\
\text { Quality Class }\end{array}$ & & n.a. & n.a. & n.a. & I & n.a. & n.a. & n.a. & I & n.a. & I & n.a. & n.a. & n.a. & n.a. \\
\hline
\end{tabular}




\subsection{Diversity and Ecology of Macrophytes and Algae}

We identified five species of macrophytes (Table 2) and three species of charophytes in studied lakes: Chara dominii Vilh. (Figure 5), Chara tomentosa L. (Figure 6), and Chara intermedia A. Braun in A. Braun, Rabenh. et Stitzenb. (Figure 7). Chara dominii was reported from single locality in Volyn Polissya [18, 22-24] and this record was the single for Europe. Unfortunately specimens of $C$. dominii were lost from Ukrainian botanical collection (according personal communication of Prof. P.M. Tsarenko, Botanical Institute, National Academy of Science of Ukraine) and this record couldn't be checked. So our collection is a checkable record for this species in Europe and a new record for Steppe in Ukraine. Chara tomentosa and C. intermedia are known from Steppe. Species Chara tomentosa is extremely rare in Ukraine. Species Chara intermedia was reported mainly for bays of Black Sea [18, 22-24] and therefore can be marked as more tolerant species.

Studied lakes surface was covered by five species of macrophytes (Table 2), diversity and percent of coverage of which are fluctuated from lake to lake and stay richer in the Flora Lake. Charophytes also were diverse in this lake and represent by two species like in the Azotnyy Lake, while only single species was found in the lake Molodezhnyy. The Flora Lake inhabits by rare species of charophytes - Chara dominii and now we only have Ukrainian specimens of this species for comparative studies.

Table 2. Diversity and ecological preferences of macrophyte and charophyte species in the studied lakes with percentage of the lake surface coverage and species autecology according [16]

\begin{tabular}{|c|c|c|c|c|c|c|}
\hline Taxa & Code & Flora & Molodezhnyy & Azotnyy & $\begin{array}{c}\text { Species-specific } \\
\text { index s }\end{array}$ & Saprobity \\
\hline Potamogeton pectinatus L. & POTPEC & 2.9 & 2.5 & 18.5 & 1.70 & b-o \\
\hline Potamogeton perfoliatus L. & POTPER & 2.9 & 2.5 & 3.7 & 2.30 & $\mathrm{~b}$ \\
\hline Potamogeton crispus L. & POTCRI & 2.9 & 0.0 & 0.0 & 2.60 & a-b \\
\hline Ceratophyllum demersum L. & CERATO & 14.7 & 0.0 & 3.7 & 2.20 & $\mathrm{~b}$ \\
\hline Myriophyllum verticillatum L. & MYRVER & 2.9 & 0.0 & 0.0 & 1.80 & o-a \\
\hline Chara tomentosa L. & CHATOM & 0.0 & 0.0 & 54.1 & 1.20 & o \\
\hline Chara dominii Vilh. & CHADOM & 14.7 & 0.0 & 0.0 & - & - \\
\hline $\begin{array}{c}\text { Chara intermedia A. Braun in A. } \\
\text { Braun, Rabenh. et Stitzenb. }\end{array}$ & CHAINT & 58.8 & 94.9 & 20.0 & - & - \\
\hline Total species & & 7 & 3 & 5 & & \\
\hline Index S & & 2.16 & 2.00 & 1.41 & & \\
\hline
\end{tabular}

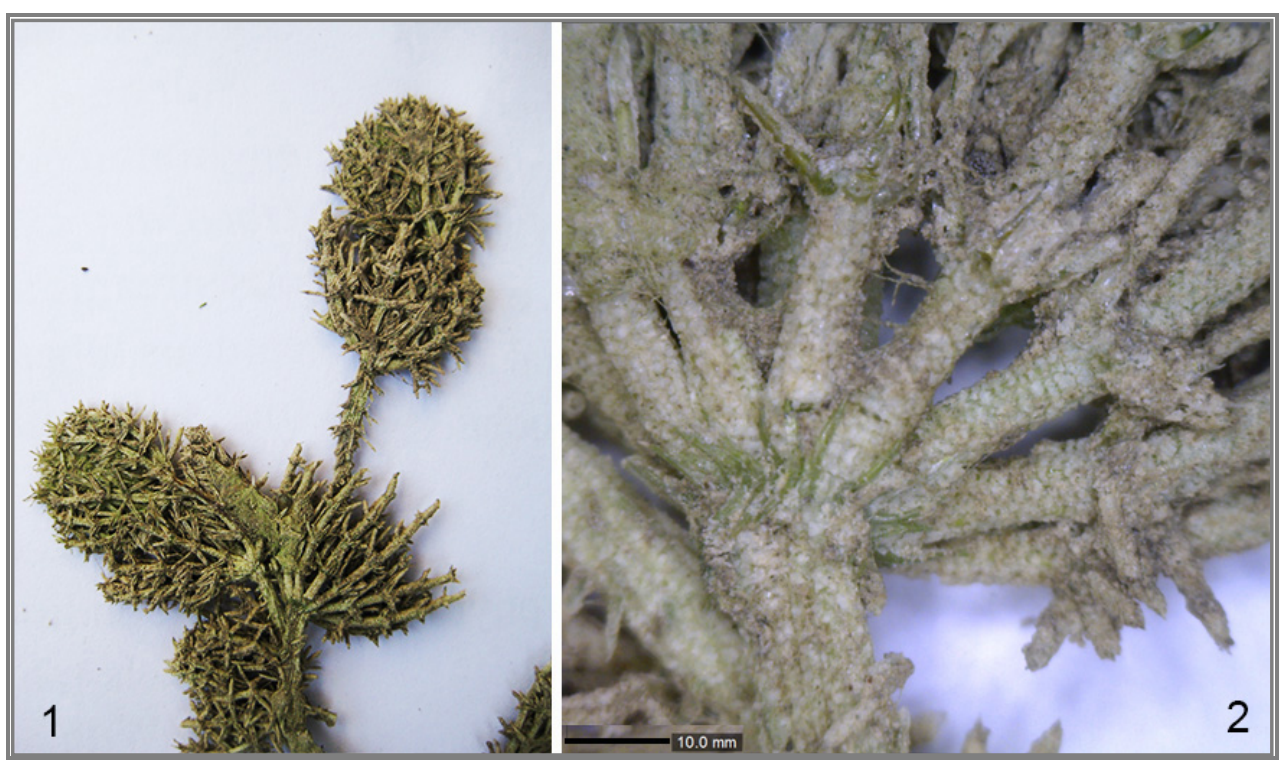

Figure 5. Chara dominii: 1 - view of thallus, 2 - axis with axial cortex, stipulodes and base of whorl 


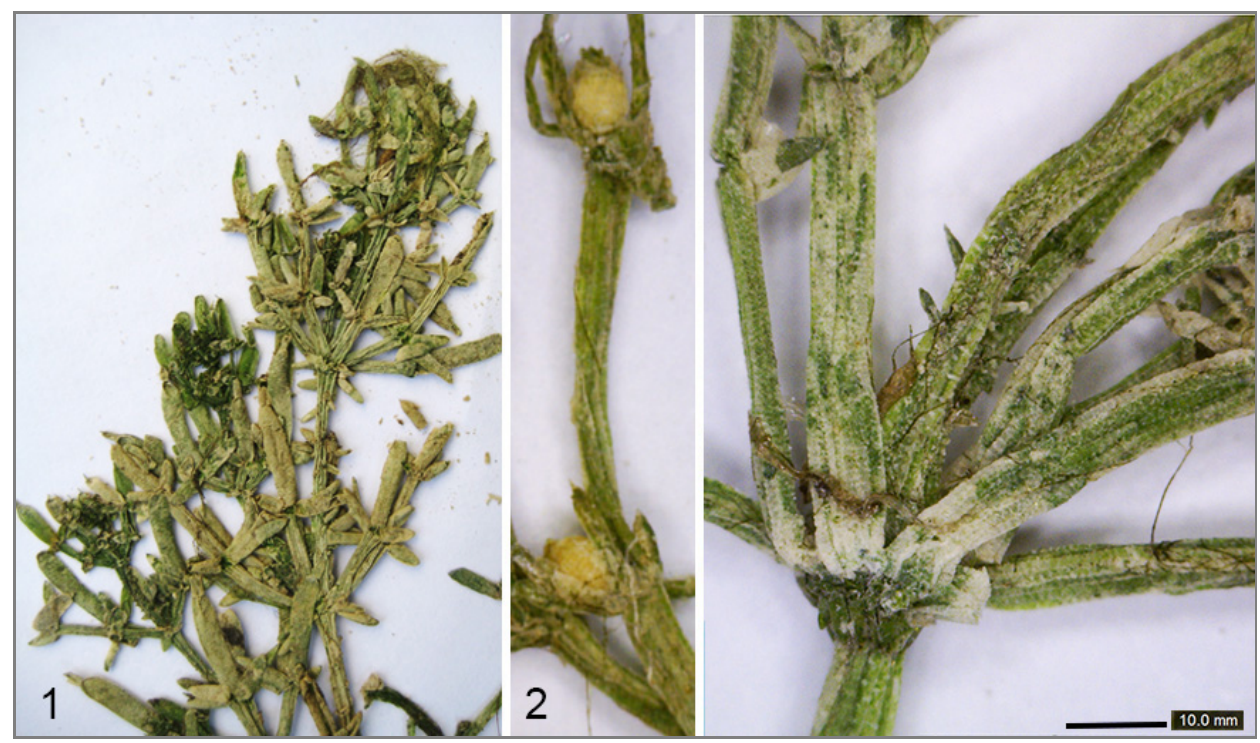

Figure 6. Chara tomentosa: 1 - view of thallus, 2 - branchlets with axial cortex and oogonia, 3 axis with axial cortex, stipulodes, base of whorl, and branchlets

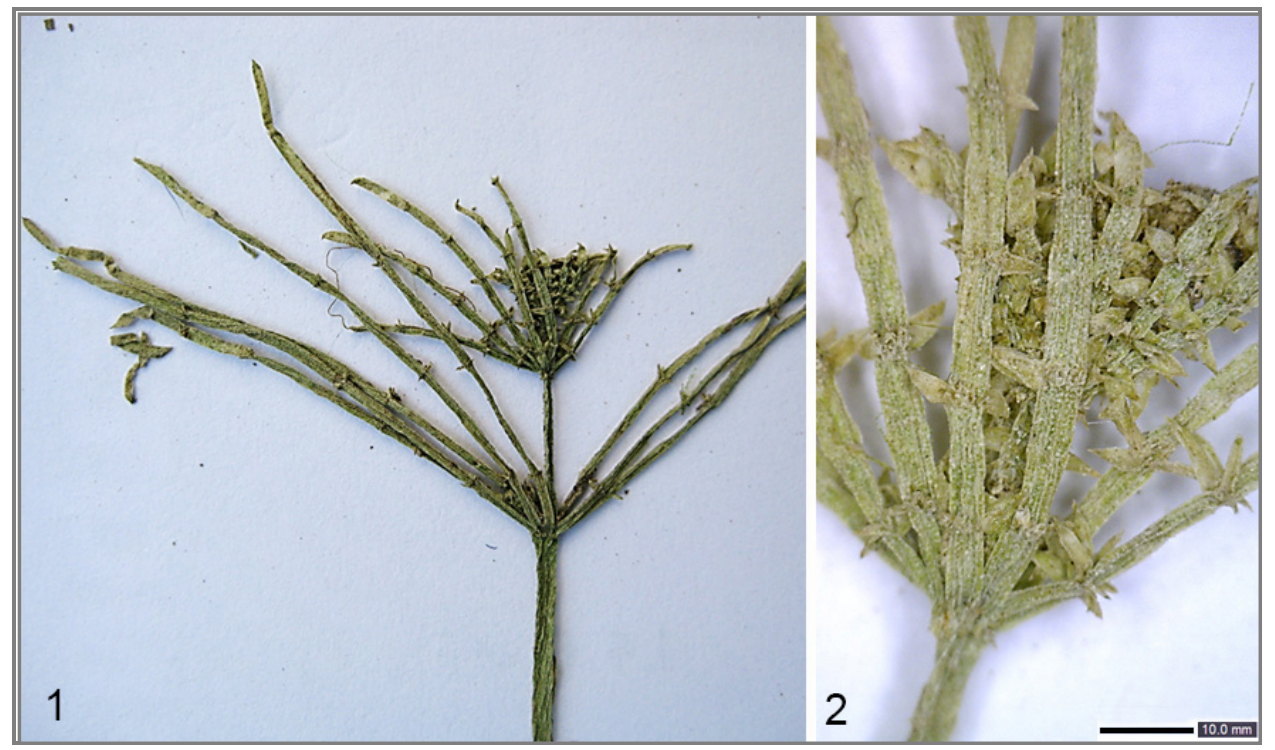

Figure 7. Chara intermedia: 1 - whorl of branchlets, 2 - axis with branchlets, axial cortex, stipulodes, and base of whorl

\subsection{Bio-indication of the Studied Lakes Environment}

We use bio-indication and statistical methods on the base of algal and macrophyte species which inhabiting the lakes in purpose to characterize of the lakes water quality and ecosystem sustainable.

Table 2 shows Index saprobity $\mathrm{S}$ value that we calculated on the base of coverage percent and species-specific index s. Water in the Flora $(\mathrm{S}=2.16)$ and Molodezhnyy $(\mathrm{S}=2.0)$ lakes was organically more polluted than in the Azotnyy lake $(S=1.41)$. Water quality in first two lakes can be assessed according to [16] as Class III, whereas Azotnyy lake water corresponds to Class II. It correlates with representation of abundant beta-mesosaprobic macrophyte Ceratophyllum demersum with index $\mathrm{s}=2.2$ in the Flora Lake, and oligosaprobic Chara tomentosa with $\mathrm{s}=1.2$ in the Azotnyy Lake. Therefore, the Flora and Molodezhnyy lakes can be characterized as mesotropic state and low to middle organic pollution, while the Azotnyy Lake was oligotrophic with low organic pollution [16].

Environmental variables and species diversity relationships were calculated with Statistica 7.1, wessa.net, and CANOCO Programs.

Water variables as a whole in the in the studied lakes are fluctuated in small range (Table 1). Nevertheless, we can see differences in respect of biological variables such as Species richness and Index Saprobity S. So, algal and plant growth in the lakes have positive correlation of species richness with Lithium (Pearson 0.75, $\mathrm{p}<.01$ ), Magnesium (Pearson 0.58, $\mathrm{p}<.04$ ), Sodium (Pearson 0.72, $\mathrm{p}<.01$ ), Silica (Pearson 0.81, $\mathrm{p}<.0001$ ), and Strontium (Pearson $0.72, p<.01)$. Index Saprobity $S$ correlated positively with 
Barium (Pearson 0.65, $\mathrm{p}<.02$ ), Lithium (Pearson 0.91, $\mathrm{p}<.001$ ), Magnesium (Pearson 0.87, $\mathrm{p}<.001$ ), Sodium (Pearson 0.57, $\mathrm{p}<.01$ ), Silica (Pearson 0.81, $\mathrm{p}<.003$ ), and Strontium (Pearson 0.72, $\mathrm{p}<.01$ ).

Macrophyte and charophyte species show its own preferences of environmental variables. So, Potamogeton perfoliatus abundance is negatively correlated with organic pollution which reflect Index saprobity (Pearson -0.86, $\mathrm{p}<.001$ ), while Potamogeton crispus and Myriophyllum verticillatum have positive correlation (Pearson $0.66, \mathrm{p}<.02$ in both cases). Chara dominii and $C$. intermedia show positive correlation of its abundance with organic enrichments (Pearson 0.66, $\mathrm{p}<.02$ and 0.77, $\mathrm{p}<.007$ respectively), but $C$. tomentosa don't show any correlation.

It was important to reveal from which sources come organic pollution that stimulated algal and macrophyte species richness and growth. We hypothesized that calcium comes from an underground supply, while easily soluble sodium from surface runoff. Figure 8 shows that Index of organic pollution has trend to increase with calcium increasing when sodium is low. In the same time organic pollution is slightly stimulated by sodium concentration also. Species richness has negative trend and increase with calcium and sodium increasing. By this can be concluded that pollution come mostly from ground source and stimulated species growth.

Figure 9 show that macrophyte Potamogeton pectinatus (and other macrophytes, as we calculated) prefer calcium and sodium enriched water, while macroalga Chara intermedia have negative preferences with low concentration of calcium and sodium. This conclusion correlated with chemical data in Table 1, and data of species representation in Table 2.

Canonical Correspondence Analysis (CCA) shows (Figure 10) that water variables are separated into two different groups. Group of manganese, potassium and iron have negative influence on most of species excluding Chara tomentosa which is stimulated in the Azotnyy Lake. All other variables including of organic pollution Index $\mathrm{S}$ are grouped in second set and stimulated growth of macrophyte Ceratophyllum demersum and charophytes Chara dominii and Chara intermedia which inhabited lakes Flora and Molodezhnyy. Interesting that this set of variables and influenced species are well growing under organic pollution increasing with groundwater input enriched by mine water as well as with surface runoff [25]. This situation looks like natural, in the initial stage of ecosystem trophic state, when species growth is stimulated by organic enrichments. The lakes with high $\mathrm{pH}$ and calcium enrichments like in England are representing especially group and has been recommended more studies be undertaken on eutrophication responses of macrophytes. In lakes where macrophyte species composition varies with water depth, eutrophication is apparent through reductions in productivity especially of Characeae and Potamogetonaceae [26] like in our lakes.

Therefore, the Molodezhnyy Lake can be used as reference site for anthropogenic impact assessment. The Flora Lake needs to more attention in research of complex influence of organic enriched and mine waters flowing into the lake from runoff or ground waters of the catchment area, whereas the Azotnyy Lake can be exposed to toxic substances, as we assume.

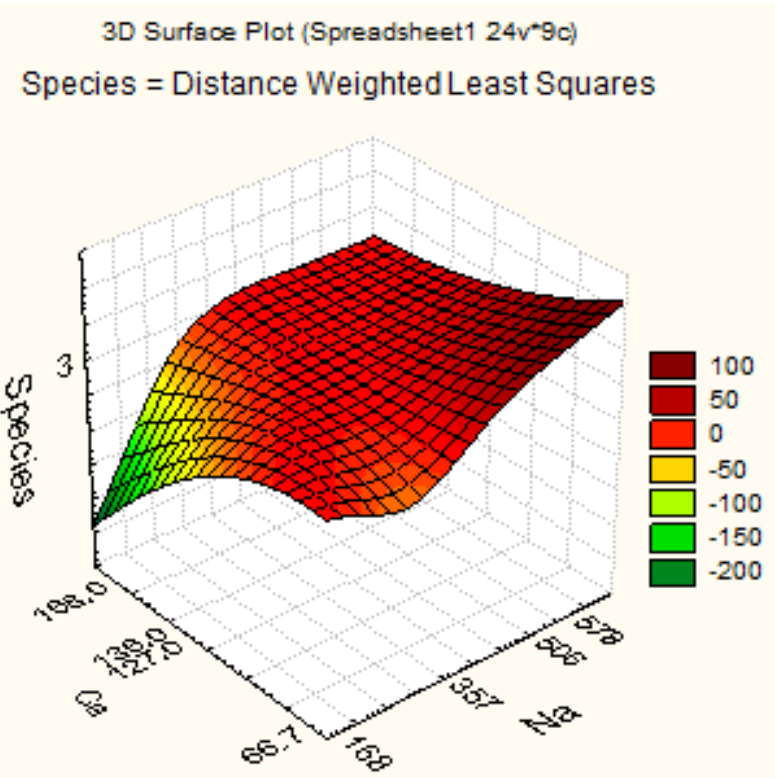

Figure 8. Water calcium, sodium, Index saprobity $\mathrm{S}$, and number of algal species relationships in aquatic communities of the Donetsk lakes. 

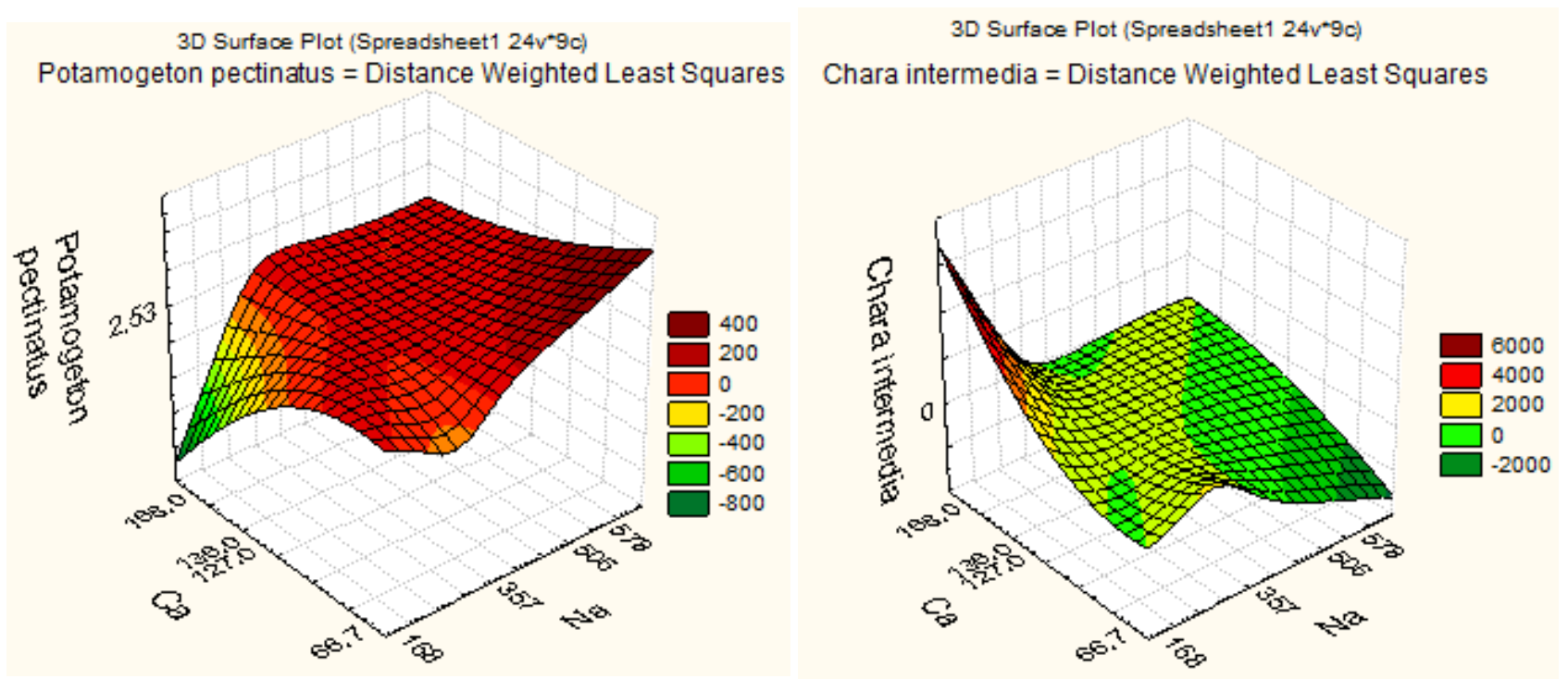

Figure 9. Water calcium, sodium, macrophyte Potamogeton pectinatus, and charophyte macroalga Chara intermedia relationships in aquatic communities of the Donetsk lakes.

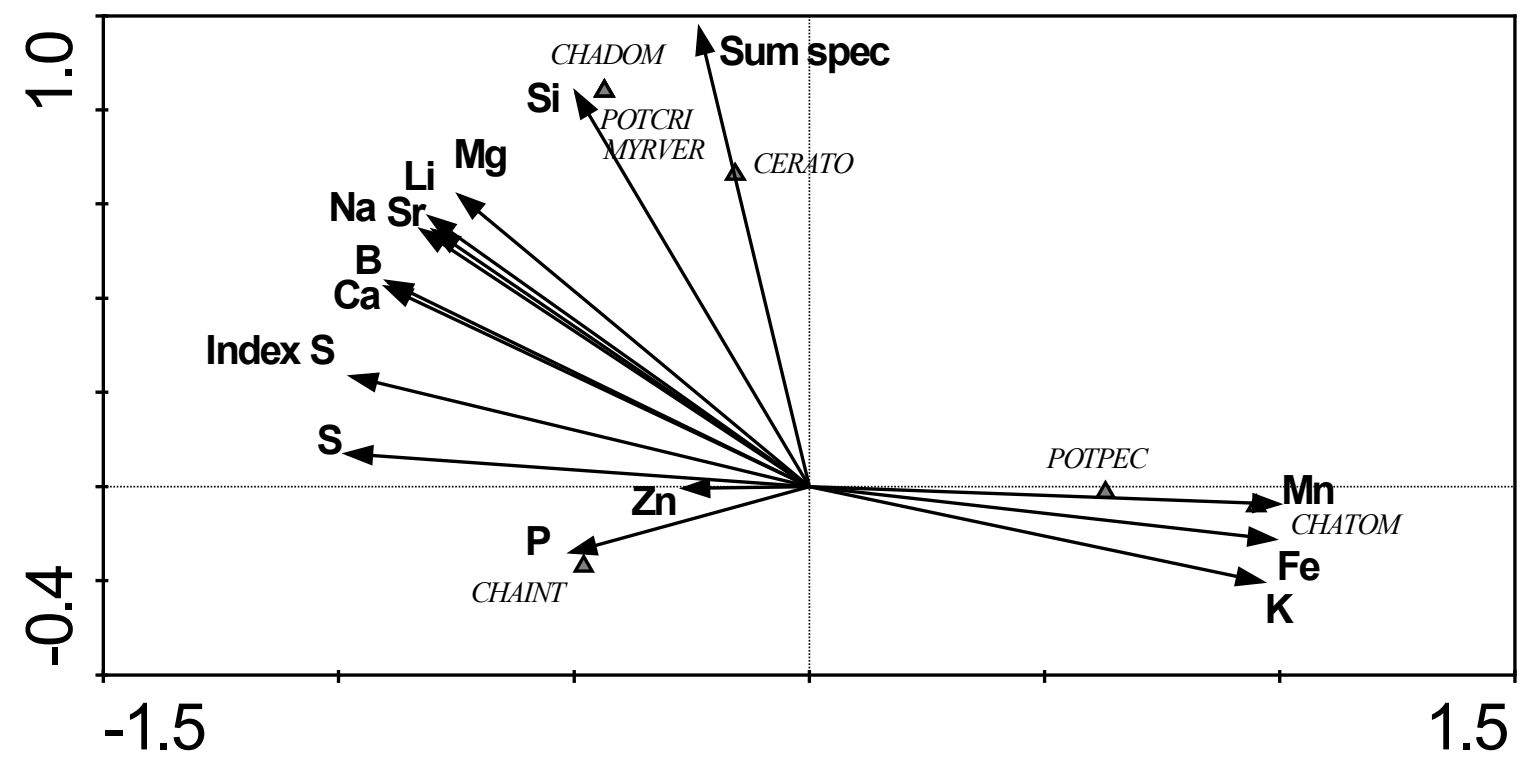

Figure 10. Canonical Correspondence Analysis (CCA) plot of species and environmental variables relationships in aquatic communities of the Donetsk lakes.

\section{Conclusions}

Three studied lakes ecosystem in the Donetsk area were in first time analyzed by bio-indication methods and statistics. As a result, we revealed five macrophyte species and three species of charophyte macroalgae. Lakes Flora and Molodezhnyy is mesotrophic and low-to middle polluted by organic matters, while the Azotnyy Lake show oligotrophic state and low organically polluted waters. Statistics pointed us that organic pollution comes mostly from groundwater enriched by mine waters and stimulated species growth together with soluble sodium from surface runoff. Whereas macrophyte species are resistant to inorganic concentration, charophytes are preferred calcium enriched waters, especially Chara intermedia is sensitive.
We can to conclude that the Molodezhnyy Lake can be marked as reference site of anthropogenic impact, the Flora Lake with inhabiting of rare species, such as Chara dominii is best object for organic pollution monitoring, and the Azotnyy Lake can be given more attention in following monitoring of toxic substances impact. Bio-indication methods implemented together with statistic approaches can be used as sensitive instrument for ecosystem state assessment and watershed protection in the technogenically impacted area such as Donetsk region of Ukraine.

\section{Acknowledgements}

We thank Professor Petro Tsarenko for the information 
on the distribution of charophyte species in Ukraine. This work is partly funded by the Israeli Ministry of Absorption.

\section{REFERENCES}

[1] E.G. Bellinger, D.C. Sigee. Fresh water algae (Identification and use as bioindicators), John Wiley and Sons, Chippenham, Wilts, UK, 2010.

[2] O. Bilous, S. Barinova, P. Klochenko. Phytoplankton of the middle section of the Southern Bug River as the index of its ecological state, Hydrobiological Journal, Vol.49, No.6: 2942, 2013.

[3] O. Bilous, S. Barinova, P. Klochenko. The role of phytoplankton in the ecological assessment of the Southern Bug River middle reaches (Ukraine), Fundamental and Applied Limnology / Archiv für Hydrobiologie, Vol.184, No.4: 277-295, 2014.

[4] V. Klymiuk, S. Barinova, N. Lyalyuk. Diversity and ecology of algal communities from the Regional Landscape Park "Slavyansky Resort", Ukraine, Research and Reviews: Journal of Botanical Sciences, Vol.3, No.2, 9-26, 2014.

[5] P.M. Tsarenko, S.P. Wasser, E. Nevo, (Eds.). Chlorophyta, V.3. In: Algae of Ukraine: diversity, nomenclature, taxonomy, ecology and geography, Gantner Verlag, Ruggell, 2011.

[6] A. Lukyanchenko (Ed.). Report on the state of the environment of the city of Donetsk in 2006-2007 years, Management of ecological safety of Donetsk City Council, Donetsk, 2008.

[7] G.I. Harhota, V.M. Povh. The flora of higher plants ponds mine in Donbass, Introduction and experimental plant ecology, Vol.5: 66-68, 1976.

[8] N.R. Ryshkovskaya. Vegetation artificial reservoirs Donbass, Donetsk State University Press, Donetsk, 1980.

[9] R.I. Burda. Anthropogenic transformation of flora, Naukova Dumka, Kiev, 1991.

[10] D. Dubina. Higher aquatic vegetation. Lemnetea, Potametea, Ruppietea, Zosteretea, Isoëto-Littorelletea (Eleocharition acicularis, Isoëtion lacustris, Potamion graminei, Sphagno-Utricularion), Phragmito-Magnocaricetea (Glycerio-Sparganion, Oenanthion aquaticae, Phragmition communis, Scirpion maritime), Fitosotsiotsentr, Kiev, 2006.

[11] J.P. Diduh. Fundamentals of bioindicators, Naukova Dumka, Kiev, (book in Ukrainian with summary in English), 2012.

[12] A.V. Fatyukha, S.V. Bespalova, N.M. Lyalyuk. Basin approach in biogeochemical monitoring of technologically transformed part of the river Kalmius (Donetsk), Problems of ecology and conservation of man-made area, Vol.1, No.12: 35-40, 2012.
[13] S. Barinova. Algal diversity dynamics, ecological assessment, and monitoring in the river ecosystems of the eastern Mediterranean, Nova Science Publishers, New York, USA, 2011.

[14] S. Barinova, C.N. Solak, O. Erdoğan, R. Romanov. Algae and Zooplankton in Ecological Assessment of the Işıklı Lake, Turkey, Aquatic Biology Research, Vol.2, No.2: 23-35, 2014a.

[15] S. Barinova, R. Romanov, C.N. Solak. New record of Chara hispida (L.) Hartm. (Streptophyta: Charophyceae, Charales) from the Işıklı Lake (Turkey) and critical checklist of Turkish charophytes, Natural Resources and Conservation, Vol.2, No.3: 33-42, 2014b.

[16] S.S. Barinova, L.A. Medvedeva, O.V. Anissimova. Diversity of algal indicators in environmental assessment, Pilies Studio, Tel Aviv (book in Russian with tables and summary in English), 2006.

[17] cyanobacteria.net in: http://www.sinice.cz/index-en.php

[18] M.M. Hollerbach, G.M. Palamar-Mordvintseva. The identification manual of freshwater algae of Ukraine, 9. The charophytes (Charophyta) (in Ukrainian), Naukova dumka, Kyiv, 1991.

[19] D.M. John, B.A. Whitton, A.J. Brook (Eds.). The freshwater algal flora of the British Isles: an identification guide to freshwater and terrestrial algae. Cambridge University Press, Cambridge, 2011.

[20] W. Krause. Charales (Charophyceae). In: H. Ettl, G. Gärtner, H. Heynig, D. Mollenhauer (Eds.), Süßwasserflora von Mitteleuropa, Band 18, pp. 1-202, Gustav Fischer Verlag, Jena, Stuttgart, Lubeck, Ulm, 1997.

[21] C.J.F. Ter Braak, P. Šmilauer. CANOCO Reference Manual and CanoDraw for Windows User's Guide: Software for Canonical Community Ordination (version 4.5), Microcomputer Power Press, Ithaca, 2002.

[22] E.V. Borisova. Species composition and distribution of Charales in the Ukraine. Int. J. Algae, Vol.7, No.1: 88-102, 2005.

[23] E.V. Borisova. The pattern of the distribution of Charales in the Ukrainian Polissya. Algologia, Vol.24, No.3: 363-367, 2014.

[24] G.M. Palamar-Mordvintseva, O.V. Borysova, P.M. Tsarenko. Results and current tasks of study on the Ukrainian Charales (in Ukrainian), Ukr. Bot. J., Vol.62, No.4: 538-547, 2005.

[25] A.V. Fatyukha, V.M. Klymiuk. Ruppia maritima (Ruppiaceae), a new species of reservoirs in Donetsk, Ukr. Bot. J., Vol.71, No.3: 330-332, 2014.

[26] E. Wiik, H. Bennion, C.D. Sayer, S.J. Clarke. Assessing the status of marl lakes under the European Union Water Framework Directive - insights from contemporary and palaeolimnological studies of three English lakes, Fundam. Appl. Limnol., Vol. 185, No.2: 121-138, 2014. 